\title{
Sheikh Nuruddin Al-Raniri Description Of Heaven In Bad 'Al-Khalq Al- Samawat Wa Al-Ard [MSS 1517(A)]
}

\author{
Mohd Solahuddin Shahruddin'1, Azri Bhari², Muaz Mohd Noor 3 , Ahmad Zuhdi Ismail ${ }^{4}$ \\ ${ }^{1}$ Postgraduate Students, Academy of Islamic Studies, University of Malaya, Kuala Lumpur \& \\ Lecturer, Academy of Contemporary Islamic Studies, Universiti Teknologi MARA, Shah Alam, Selangor., Malaysia. ${ }^{2}$ Senior Lecturer, \\ Academy of Contemporary Islamic Studies, Universiti Teknologi MARA, Shah Alam, Selangor, Malaysia. ${ }^{3}$ Lecturer, Academy of \\ Contemporary Islamic Studies, Universiti Teknologi MARA, Alor Gajah, Melaka, Malaysia. ${ }^{4}$ Senior Lecturer, Academy of Islamic \\ Studies, University of Malaya, Kuala Lumpur, Malaysia.
}

\begin{abstract}
Sheikh Nuruddin al-Raniri (d. 1658) is a renowned scholar in the Malay archipelago during the rule of Sultan Iskandar Thani (1636-1641 AD) in Acheh. He had authored 35 works on various disciplines of Islam and Bad 'al-Khalq al-Samawat wa al-Ard describes the concept of heaven genesis in Jawi manuscript MSS1517 (A). This article is a preliminary analysis of the manuscript focusing on excerpts of al-Raniri's exposition on the meaning of heaven and its categories. That heaven has respective names and inhabitants in the Day of Judgment. Study on the biography of al-Raniri and the written scripture was conducted by analyzing al-Raniri's thinking pattern, which was extracted from the book. Moreover, the concept of the natural phenomenon was explained and discussed intensively following Islamic thinking. Then each phrase and al-Raniri's ideology was clearly defined base on the interpretation of Qur'an and hadiths. Result of this study shows that the writing method done by al-Raniri was mostly focusing on imagining the condition of a specific place in heaven.
\end{abstract}

Keywords: al-Raniri; Bad 'al-Khalq al-Samawat wa al-Ard; heaven; earth

eISSN: 2398-4287 @ 2020. The Authors. Published for AMER ABRA cE-Bs by e-International Publishing House, Ltd., UK. This is an open access article under the CC BYNC-ND license (http://creativecommons. org/licenses/by-nc-nd/4.0). Peer-review under responsibility of AMER (Association of Malaysian Environment-Behaviour Researchers), ABRA (Association of Behavioural Researchers on Asians) and cE-Bs (Centre for Environment-Behaviour Studies), Faculty of Architecture, Planning \& Surveying, Universiti Teknologi MARA, Malaysia.

DOI: https://doi.org/10.21834/ebpj.v5iSI1.2300

\subsection{Introduction}

Sheikh Nuruddin al-Raniri full name is Nur al-Din Muhammad ibn Ali ibn Hasan-Ji ibn Muhammad Hamid(al-Attas, 1986) al-Qurayshi alShafi'i al-'Ash'ari al-'Aydrusi al-Raniri (Al-Attas, 1986). He was born in Ranir (Rander), near a well known old port in Gujarat, India. His birth date is unknown for historians do not record it. He was born into a diaspora Hadhrami family of Hamid clan. The family members of Sheikh Nuruddin al-Raniri were mostly emigrants and settled in a city around the port area of the Indian Ocean and the Malay Archipelago Indonesia.

\subsection{The Bad' Al-Khalq Al-Samawat Wa Al-Ard Manuscript}

Al-Raniri manuscript Bad' al-Khalq al-Samawat wa al-Ard means ' means 'The Genesis of the Heaven and Earth'. It is a theological history in concept. It is an excerpt from the first chapter of the book entitled Bustan al-Salatin. It was informed in his name. Generally, Al-Raniri's Jawi scripture of Bada' al-Khalq al-Samawat wa al-Ard highlights the creation of the universe or Heaven and Earth by Allah SWT and also the cosmological relationship of every nature (Al-Attas, 1969).

eISSN: 2398-4287 @ 2020. The Authors. Published for AMER ABRA cE-Bs by e-International Publishing House, Ltd., UK. This is an open access article under the CC BYNC-ND license (http://creativecommons.org/licenses/by-nc-nd/4.0/). Peer-review under responsibility of AMER (Association of Malaysian Environment-Behaviour Researchers), ABRA (Association of Behavioural Researchers on Asians) and cE-Bs (Centre for Environment-Behaviour Studies), Faculty of Architecture, Planning \& Surveying, Universiti Teknologi MARA, Malaysia.

DOI: https://doi.org/10.21834/ebpj.v5iSI1.2300 
The book was published several times in Mecca, Egypt and Southeast Asia. Among them is Matba'ah Dar Ihya 'al-Kutub al-Arabiyyah that was published by' Isa al-Babi al-Halabi \& Co, Egypt in 1344H. Haji Darwish Kati al-Azhari translated it into the Malay language in Jawi scripture. This book has also been printed along with the text of Taj al-Mulk written by Haji Ismail Aceh.

The analysis of al-Raniri description on heaven is by comparing it to the verses of al Qur' an on heaven, and also hadiths and sunnah of the Prophet SAW. The criteria being that the description should not contradict the verses and the hadiths, and free from Israiliyat elements.

\subsection{Heaven in the Qur'an}

Heaven was informed in the Qur'an for 145 times in the term of al Jannah. Jannah is described as a pleasant garden (Qur'an, 4:57), adorned with infinite majesty, shaded by numerous shady trees (al-Qur'an, 76:20) and sheltered from the cold and hot weather (Qur'an, 4:57; Cyril Glasse, 1999). Al-Jannah is a place that was provided by Allah S.W.T for the righteous servants as a reward for their faith and good deeds they have done in this world. The residents of heaven will be indulged by various pleasures, which have never been seen by the eyes, or heard by the ears or crossed by the minds and hearts of human beings.

Heaven in an eternal abode created by Allah SWT for the righteous servants as a reward for their faith and good deeds they have done. Various pleasures, which have never been seen by the eyes, will be enjoyed by the heaven inmates (Hassan Ayub, 1994). Thus, the word al-Jannah refers to a garden with palm trees and vines with heavy foliage and swirling branches that can shade and cover up what is underneath them. Moreover, there are flowing rivers, a quiet and comfortable atmosphere. In the Qur'an, the word al-Jannah and its genesis are mentioned 145 times (Mujjam al-Mufahris, 180-182) in 58 verses (Bihār al-Anwār, 71-80). Heaven is an interesting topic regularly discussed among mutakallimūn. An inquiry which has raised speculation whether the Heaven was made into a reality (haq) or unseen (majazi), created (makhlūq) and eternal or perish. Among al-Asyāirah, al-Razi, for instance, believes that Heaven is a reality based on the description of the Quran.(Usūl al-Dīn, 119-120 ; Qur'ān, 2:24 \& 3:133)

A most reliable explanation of the measurement in Heaven is mentioned in a hadith Qudsi:

"I have prepared to my righteous slaves, something that has never been seen by the eyes, heard by the ears and imagined by the hearts."

(Sahih, 2174-2175; Al-Qur'ān, 32:17; al-Falsafah;116)

\subsection{Discussion}

Raniri's manuscript of Bad' al-Khalq al-Samawat wa al-Ard discusses the genesis of the creation of earth and heaven by Allah SWT. There are 30 clauses in the manuscript that addresses the nature of heaven and the universe related to Israiliyat elements (Abdul Kadir, 1989). The description of heaven, as mentioned by Sheikh Nuruddin al-Raniri, is based on the Quran verses and hadith. These include a description of the doors to the haven, their environment and inhabitants. The fact is that heaven is eternal and the focal point of human desire.

Special entrance to heaven is its many doors. The doors of various heavens are the route through which humankind enter heaven to be blessed by the ultimate rewards that Allah SWT has promised. Raniri mentioned various doors of Paradise. The first door in the heaven (Jannah al-Khuldi) is made of red gems, the second door (Jannah al-Firdaus) is made of gold, the third door (Jannah al-Makwa) is made of green Emerald while the fourth door (Jannah 'adni) is made of pearls.

Further, Al-Raniri had cited two verses of the Quran in explaining the depiction of Heaven doors. According to al- Raniri, based on Quran passages, there are two doors of Heaven, and each door has another two more entries in it. It is based on the surah alRahman chapter 46 and 62 . Kalam scholars have various assumptions on the number of Heaven names. Some of them mentioned of eight, seven and four altogether about the number of Heaven name (Mustafa Ahmad 'Aqbawi,1949). Heaven names quoted are alFirdaus, 'Adn, al-Khuld, al-Na'im, al-Ma'wa, dar al-Salam, dar al-Jalal, 'lliyin, dar al-Mazid, dar al-Muttaqin, dar al-Muqamah dan dar alQarar (Abu Bakr Jabir al-Ja'izi, 1986). Furthermore, there are also words referring to heaven in the Quran such as Raudah, Fadl, alHusna, dar al-Akhirah, al-Ghurfah and 'Uqbah al-Dar (Muhammad Khalil 'Aitani, 2000).

Therefore, Al-Raniri's views appear to be accurate that heaven has several names and of different levels. This medium is according to his broad division of heaven in his manuscript. Al-Raniri also classified Heaven not only by names but also according to the Heaven doors and those eligible to be the residents.

While, verses on the creation of the doors of heaven have not been found in the translation and explanation (Tafseer) of al-Qur'an, except the names of paradise given by Allah S.W.T. The al-Raniri manuscript is found to contain some Israiliyyat elements on the creation of heaven doors. Kalam scholars have varied responses on the number of the doors of the Heaven and their names. Some of them claimed the total number of heaven doors is eight, and others posited seven or four, or twelve altogether as the names quoted as al-Firdaus, 'Adn, al-Khuld, al-Na'im, al-Ma'wa, dar al-Salam, dar al-Jalal, 'Illiyin, dar al-Mazid, dar al-Bar, dar al-Muqamah and dar alQarar.

In the Qur' an, heaven is mentioned as Raudah, Fadl, al-Husna, dar al-Akhirah, al-Ghurfah and 'Uqbah al-Dar. Further, heaven is mentioned to be six doors (bab), which are Bāb al-Rahmah, Bāb al-Sabr, Bāb al-syukr, Bāb al-Älam and Bāb al-Akbar. Al-Raniri stated that heaven has several names and different levels, and this statement is the core of his exposition of heaven. Heaven consists of several levels, and each level is a unique abode for specific and chosen believers. In tandem with heaven and these levels, al-Raniri also elaborated on the doors of the heaven through which the blessed dwellers shall enter their respective abode. 


\subsection{Finding}

There are eight names of heaven mentioned in the Qur'an, such as Firdaus, 'Adn, Naim, Ma'wa, Darussalam, Darul Muamah (Darul Jalal), al-Maqamul and Khuldi. Each of this heaven is an abode for only preferential residents who are rewarded according to their good deeds in the world.bSurah al-Mukminun revealed that the Firdaus is for those who are diligent in prayers, avoid vain things, pay zakat, abstain themselves from illicit sex, truthful in keeping trust and covenants, and true worshipper of Allah SWT. Meanwhile, the 'Adn will be occupied by the righteous, tolerant people of good deeds and whose wealth is used in the path of Allah. While the Ma'wa is an abode for those who fear Allah SWT, do good deeds, and control their lusts and desires. The Darussalam is inhabited by those who faithful to Islam, obedient servant of Allah SWT.

The Darul Muqamah (Darul Jalal) is resided by the people of strong faith in Islam. They who are always doing just and rarely make mistakes. Heaven of Amin al-Maqamul is home for those who fear Allah SWT. Lastly, the heaven of Khuldi is for the people who obey the commands of Allah and avoid His prohibitions. Al-Raniri mentioned seven doors of heaven through which their blessed residents enter their abode. First is the gate of Dar al-Jalal, which is made of white pearls and a place for the servants who repented their sins. Next, is the door of Dar al-Salam, which is made of red rubies. A suitable residence for those who bore great patience and endured the most hardship in life. Then, is the door of Jannah al-Makwa, which is made of zabarjad green gemstones. The chosen people who would stay in are those who fear Allah SWT.

Next, Jannah al-Khuldi that is made of a red pond. They're in it, exists gold that is in red. This place is for all the rightful servants of Allah S.W.T. The fifth, Jannah al-Naim is made of white silver, and this is a dwelling for the servants who love Allah S.W.T. Jannah alFirdaus is in the sixth heaven, and it is made of red gold. The above is for the servants who have to accept life destiny with an open heart. The last door is Jannah Dar al-Qarar, that is made of musk. The musk has the most beautiful fragrant and this eternal dwelling is for the servants who love Allah SWT.,

All of these heavens door are mentioned in the al Qur'an and discussed by various Muslim scholars. Al-Raniri elaborates on the heaven doors made of gemstone, gold, silver, pearl and many more. Al-Raniri's has based his description on the holy verses of al Qur'an and Hadiths. Al-Raniri also cited Ibn Abbas, who mentioned that the first type of people who will enter through the first door of heaven are the prophets, martyrs and benefactors. Second, are pious people who care most on their worship and prayer. Then, people who had paid some of their treasurers as zakat enters through the third door.

Next, the fourth type of people that will enter from this door is the people who do good deeds and avoid evil deeds. The fifth type of people chosen to open the gate is who that control their lust and desires. Furthermore, they prevent themselves from demoralized their behaviour. The sixth, are those who have performed their pilgrims in the name of Allah. Subsequently, people in the seventh position, to enter the door, are those who strived in the path of Allah SWT. The last type of chosen people to come through this door are the righteous people. Al-Raniri described the rivers in heaven that the first river is Jannah 'adni.

Table 1.0: Description of Heaven

\begin{tabular}{|c|c|c|c|c|c|}
\hline No. & Door & $\begin{array}{l}\text { Make of Frame } \\
\text { Door }\end{array}$ & $\begin{array}{l}\text { Name of } \\
\text { Door }\end{array}$ & Dwellers & Rivers \\
\hline 1. & $\begin{array}{l}\text { Jannah al- } \\
\text { Khudi }\end{array}$ & Red Stones & $\begin{array}{l}\text { Dar al-Jan / } \\
\text { Dar al-Jalal }\end{array}$ & Repentant Servants & $\begin{array}{l}\text { - Al-Adni, } \\
\text { - Of gold, } \\
\text { - Vastness of expanses like heaven and } \\
\text { earth, } \\
\text { - Walls of golden rocks, } \\
\text { - The water of pure white as milk, sweet to } \\
\text { taste like honey. }\end{array}$ \\
\hline 2. & $\begin{array}{l}\text { Jannah al- } \\
\text { Firdaus }\end{array}$ & Red Gold & $\begin{array}{l}\text { Dar al- } \\
\text { Salam }\end{array}$ & $\begin{array}{l}\text { Servants who are patient and full acceptance of } \\
\text { decree (Qadr) }\end{array}$ & $\begin{array}{l}\text { - Rahmat } \\
\text { - Banks of pearls, } \\
\text { - Water purer than dew and sweeter than }\end{array}$ \\
\hline 3. & $\begin{array}{l}\text { Jannah al- } \\
\text { Makwa }\end{array}$ & Zabarjad Green & - & Servants who fear Allah & - Kafur \\
\hline 4. & Jannah 'Adni & White pearls & $\begin{array}{l}\text { Dar al- } \\
\text { Akhirah }\end{array}$ & $\begin{array}{l}\text { Servants who are high above in heaven } \& \text { below } \\
\text { the Arasy ar-Rahman }\end{array}$ & - Tasnim \\
\hline 5. & $\begin{array}{l}\text { Jannah al- } \\
\text { Naim }\end{array}$ & White Silver & - & Servants who love Allah SWT & - Salsabila \\
\hline 6. & $\begin{array}{l}\text { Jannah al- } \\
\text { Firdaus }\end{array}$ & Red Yakut & - & - & - Rahiq al-Makhtum \\
\hline 7. & $\begin{array}{l}\text { Janah Dar al- } \\
\text { Qanar }\end{array}$ & Musk & - & Servants who love Allah SWT & - Zanjabil \\
\hline
\end{tabular}

The river banks are made of red gold. The space between two banks is of considerable distance as far as Earth and sky. The banks of the river are adorned with gold and silver right down to the bottom of the river. The river produces a fragrant smell of musk, 'inbar and zafaran. As the river is located in a room in heaven, the wall of the room is decorated with white pearl and red gemstone of yaqut. Even the door of the room is made of precious gemstone. 
The second river in heaven is kauthar, which is the main river, whose water flows throughout other rivers in heaven. Its water is white as milk and tastes sweet as honey. Both banks of the river are adorned with red gemstones, white pearls and some claimed the stone is mixed of diamond (yaqut) stone (red colour).

There is no source to prove al-Raniri's claim about the river in 'adni heaven. The verse in the Quran mentioned that river in heaven is signified in the form of milk and the taste is sweet as honey. Regardless of that, al-Raniri indicated the presence of a space, like a room could be proven from the translation. Rasulullah S.A.W said that al-Ghurfatu is built from various gemstones of a specific colour. They are yaqut (red colour), zabarjad (green colour) or pearl (white).

The purity of the gemstones is without any defect. It is shown that the purity of the gemstone is whole. No trace of diffraction or joints on the gemstones. Heaven space can be portrayed as vast as watching a star from the east or west horizon. There are rooms that can be seen from outside into the interior and vice versa. It is known those rooms and spaces are reserved for people who hold their tongue and speak only of goodness. They also spend their wealth on food for the poor. They are those who regularly fast and worship Allah SWT, day and night and tahajud all their life.

Raniri mentioned river al-Kauthar as belonging to Prophet Muhammad S.A.W. It is quoted in surah al-Kauthar and mentioned in authentic hadith. Happiness and pleasures of heaven are challenging to be explained due to the limitation of human intellect and intuition. However, the Prophet describes the al-Kauthar river as situated in heaven in the hadiths.

Table 2.0: Doors of Passage for Dwellers of Heavens

\begin{tabular}{ll}
\hline Door & Heaven Dwellers \\
\hline First Door & A gate of heaven for all the Anbia \\
Second Door & An entry of heaven for the servants who are faithful in solah. \\
Third Door & A door of heaven for zakah givers \\
Fourth Door & A gate of heaven for servants who do good deeds \\
Fifth Door & An entry of heaven for servants who control their lust and commit no injustice \\
Sixth Door & A door of heaven for servants who perform haji \& umrah \\
Seventh Door & A gate of heaven for servants who perform fisabilillah. \\
Eight Door & A door of heaven for servants who protect their sights and do good deeds to their parents. \\
\hline
\end{tabular}
(Source: On Creation of Heaven in manuscript MSS 1517(A).)

\subsection{Conclusion}

Al-Raniri's Jawi scripture of Bad' al-Khalq al-Samawat wa al-Ard highlights heaven numerous pleasures and how desires of residents are fulfilled as they wish. Al Raniri's also had interpreted heaven and its categories and heaven's doors, of frames which are made of gold, silver, gems and diamonds. That each of the heaven vicinity has rivers of milk, honey and wine to be consumed by the residents whenever they desire to drink them. Al Raniri also highlights the endless wonders of heaven that cannot be visualized by any human imagination. That dwellers of heaven experience gratification of pleasure by only a levity of their mind, and the rewards would be presented upon them. Indeed al Raniri's Bad' al-Khalq al-Samawat wa al-Ard should be further analysed for its outstanding description of the heaven and earth and cosmology. Teaching and understanding of Jawi need to be reinforced to enable continuity for learning and research of the works of scholars in the Nusantara.

\section{Acknowledgments}

This research was funded the LESTARI grant 600-IRMI/DANA KCM 5/3/LESTARI (183/2017) from Institute of Research Management Centre. Universiti Teknologi MARA (UITM). Hopefully, this will be an encouragement for us to serve for the sake of religion, race, and nation.

\section{References}

Al-Qur'an Al-Karim (2002), tafsir ar-Rahman. Kuala Lumpur: Jabatan Kemajuan Islam Malaysia

'Abd al-Bāqī, Muhammad Fu'ad, Al-Mu'jam al-Mufahras li Alfaz al-Qur'an al-Karim. Dar al-Kutub al-Misriyyah, al-Qahirah, 1346 H.

'Abd. al-Rahman Qasim, Hasiyah Ibn Qasim 'ala Raudil Murbi'. Al-Qaherah: Huquq al-Tiba' Mahfuzah, 1397 H.

Abu Bakr Jabir al-Ja'izi (1986), 'Aqidah al-Mu'min. Jeddah: Dar al-Syuruq li al-Nashr wa al-Tauzi wa al-Tiba'ah, p.363.

Abu Bazli Abdul Kadir B. Che Kob, (1989), Aqidah Dan Keimanan. Yayasan Dakwah Islamiah Malaysia, Kuala Lumpur.

Ahmad bin al-Mubarak (t.t), Al-Ibriz min Kalam 'Abd al-'Aziz al-Dibbagh. T.T.P Maktabah al-Sya'biyah, pp.550.

Ahmad Daudy, N.A (1983), Allah dan Manusia dalam Konsespsi Syeikh Nuruddin ar-Raniri. Jakarta.

Al-Attas (1986), A Commentary on the Hujjat al-Siddiq of Nur al-Din al-Raniri. Kuala Lumpur: Ministry of Culture, p.3

Al-Bukhari (2000), Sahih al-Bukhari. Riyadh: Dar al-Salam li al-Nashr wa al-Tawzi, pp.405. 
Al-Majlisi, Muhammad Baqir (m. 1111H/1691 M), Bihar al-Anwar al-Jamiah li Durar Akhbar al-A'immah al-Athar, cet. ke-2. Beirut: Mu'assasah al-Wafa, 1403 H/ 1983 M.

Al-Razi, Fakhr al-Din Abu 'Abd Allah b. Muhammad b. 'Umar (m. 502H/ 1109 M) Mafatih al-Ghayb @ Tafsir al-Kabir. Misr: al-Maktabah al-Bahiyyah, al-Misriyyah, 1345 $\mathrm{H} / 1935 \mathrm{M}$.

Al-Saduq, Abu Ja'far Muhammad b. 'Ali Hussayn b. Musa b. Babawayh al-Qummi (m. 381 H/991 M) Ma'ani al-Akhbar, Intisyarat Islami. Najaf: Dar al-Kutub al-Islamiyyah, $1378 \mathrm{H}$.

Al-Tirmidhi, Abu 'Isa Muhammad b. 'Isa b. Sarwah (m. 297/892 M), Al-Jami' al- Sahih @ Sunan al-Tirmidhi, cet. II, Misr: Matba'ah Mustafa, al-Babi al-Halabi,1395 H/ $1975 \mathrm{M}$.

Ensiklopedia Islam (ringkas) Cyrill Glasse. Ghufron A. Mas'adi (terj.),c.2. Jakarta:Fajar Interpratama Offset, pp. 192.

Encyclopedia of Islam Indonesia, new edition. Syed Muhammad Naquib Al-Attas

Fu'ad Kharza' al-'Aqli (t.t), Dirasah fi al-'Aqidah al-Islamiyyah, T.T.P. Huquq al-Taba' wa al-Nashr Mahfuzah li al-Muallif, pp.205

Hassan Ayub (1994), Tabsit al-'Aqa'id al-Islamiyyah, c. 6. T.T.P. Dar al-Tauzi' wa al-Nashr wa al-Islamiyyah, pp. 199.

Ibrahim al-Laqani (t.t), Jawharah al-Tauhid ma'a Hashiatuha Tuhfa al-Murid. Qaherah: Matba'ah al Istiqamah,p.183.

Manuskrip Perpustakaan Negara, MSS 1517(A) (Melayu-Jawi) Khalq Al-Samawat Wa Al-'Ard, fol,4.

Muhammad Khalil 'Aytani, al-Mu‘jam al-Mufassal li Mawadi' al-Qur'ān al-Munazzal. Beirut: Dār al-Ma'rifah, 2000, pp.35-36.

Mujamma' al-Lughah al-'Arabiah (1970), Mu'jam Alfaz al-Qur'an al-Karim, j.1, c.2. T.T.P: al-Hay'ah al-Misriyah al-'Ammah li al-Ta'lif wa al-Nashr, pp. $224-225$.

Mustafa Ahmad 'Aqbawi (1949), Hasyiah ‘ala Syarh 'Aqidah al-Dardir. Qaherah: Mathba'ah Mustafa al-Babi al-Halabi wa Auladih bi Misr, pp.27.

Sayyid Sabiq (t.t). al-Aqa'id al-Islamiyyah. Beirut: Dar al-Fikr, p.301.

Syed Muhammad Naquib Al-Attas (1969), Preliminary Statement On A General Theory Of The Islamization Of The Malay-Indonesia Archipelago. Kuala Lumpur. p.29-30

Syeikh Nuruddin Muhammad Jilani al-Raniri (t.t) Bad' Khalq al-Samawat wa al-'Ard, Dicetak di tepi (bi Hamish), Haji Ismail Aceh, Taj al-Mulk. Thailand: matabah wa Matba'ah Muhammad al-Nahdi wa Awladih. 